\title{
O.M. Hapanoвa
}

Кафедра урології, оперативної хірургії та топографічної анатомії (зав. - проф. В.П. Стусь)

Д3 “Дніпропетровська державна медична академія МОЗ Украӥни”

\section{АНАЛІЗ РЕЗУЛЬТАТІВ МОРФОЛОГІЧНОГО ДОСЛІДЖЕННЯ ЯЄЧОК ЩУРІВ, ОПРОМІНЕНИХ ЕЛЕКТРОМАГНІТНИМ ПОЛЕМ ІЗ ОДНОЧАСНИМ ОТРИМАННЯМ НАСТОЯНКИ ЕХІНАЦЕЇ ПУРПУРОВОї}

\begin{abstract}
Резюме. В даній експериментальній роботі підведені підсумки морфологічного дослідження яєчок щурів, опромінених промисловим електромагнітним полем, які потім отримували $7 \%$ спиртову настоянку ехінацеї пурпурової. Доведено, що електромагнітне поле високої напруги викликає в тканині яєчок морфологічні порушення базальної мембрани, сперматогенного епітелію, інтерстиційного простору. Виявлені зміни відбувалися на рівні мікроциркуляторного русла сім'яників. Вживання тваринами імуномодулятора викликає позитивні зміни в структурі яєчок і тим самим сприяє покращенню процесу сперматогенеза.
\end{abstract}

Ключові слова: щур, сім'яні канальці, електромагнітне поле, ехінацея пурпурова.

Активний розвиток промисловості в Україні викликає зацікавленість науковців до вирішення проблеми знешкодження негативного впливу шкідливих факторів на організм працівників виробництва. Електромагнітне поле (ЕМП) присутнє при виробничих процесах на металургійних, хімічних та інших підприємствах. Найбільш чутливими до дії ЕМП вважаються такі органи, як серцево-судинна система, орган зору, а також чоловічі статеві органи. Безпечна щільність випромінювання у вигляді максимального рівня 5 $\mathrm{mBT} / \mathrm{cm}^{2}$ значно нижче, ніж для інших чуттєвих до опромінення органів. Після опромінення яєчок може наступити тимчасове або постійне безпліддя $[1,2]$. Пошкодження статевих тканин ЕМП вважається особливим питанням, тому що деякі генетики вважають, що наслідки цього впливу в вигляді мутації генів можуть проявитися через декілька поколінь. Дегенеративні зміни в яєчках щурів при 10-хвилинному опроміненні мікрохвилями виникають при підвищенні температури до $30-33^{\circ} \mathrm{C}$. Багаторазове опромінення 3-сантиметровими хвилями тканини яєчок на $3,3^{\circ} \mathrm{C}$ призводило до атрофії сім'яних канальців [3].

Мета дослідження: проаналізувати морфологічні показники яєчок щурів, одержаних після опромінення тварин ЕМП високої напруги низької частоти у різні терміни спостереження.

Матеріал і методи. Матеріалом даного дослідження слугували 230 статевозрілих білих щу- рів-самиів вагою 180-200 г віком три місяиі, які були розподілені на 4 групи: I група - контрольна (5 щурів); II група - тварини, які внутрішньошлунково одержували 7\% спиртову настоянку ехінацеї пурпурової в дозі 0,0018 мл/__(75 шурів), III група - тварини, які опромінювались ЕМП (75 щурів), IV група - тварини, які опромінювались ЕМП, а потім одержували настоянку імуномодулятора (75 щурів). Тварин експериментальної групи опромінювали ЕМП напругою $750 \kappa B$ частотою 50 Гц на підстаниіі “Дніпропетровська” $м$. Дніпропетровська впродовж 14, 30, 45, 90 та 120 діб кожного дня 1,5 год. Потім тварин виводили з експерименту методом дислокації шийних хребців під ефірним наркозом. 3 тканини сім'яників виготовлялись гістологічні препарати, забарвлені гематоксилін-еозином. Забарвлені зрізи органів вивчалися в бінокулярному мікроскопі "Leica СМЕ” та світловому мікроскопі “Біолам”. За допомогою бінокулярної сітки Автанділова вимірювалось відсоткове співвіднотення вмісту сім'яних канальців $i$ інтерстиційної тканини яєчок щурів.

Результати дослідження та їх обговорення. В контрольній групі тварин вміст звивистих сім'яних канальців яєчок щурів становив у середньому $75,28 \pm 1,45 \%$, інтерстиційної тканини $24,72 \pm 2,15 \%$.

У групі тварин, які опромінювались ЕМП, а потім отримували імуномодулятор - 7\% спиртову 
настоянку ехінацеї пурпурової, одержані наступні зміни: у всіх трьох серіях експерименту вміст звивистих сім'яних канальців в одиниці площі до 30ï доби спостереження коливався на рівні від $75,11 \pm 3,66 \%$ до $76,65 \pm 2,36 \%$ (рис. 1 ).

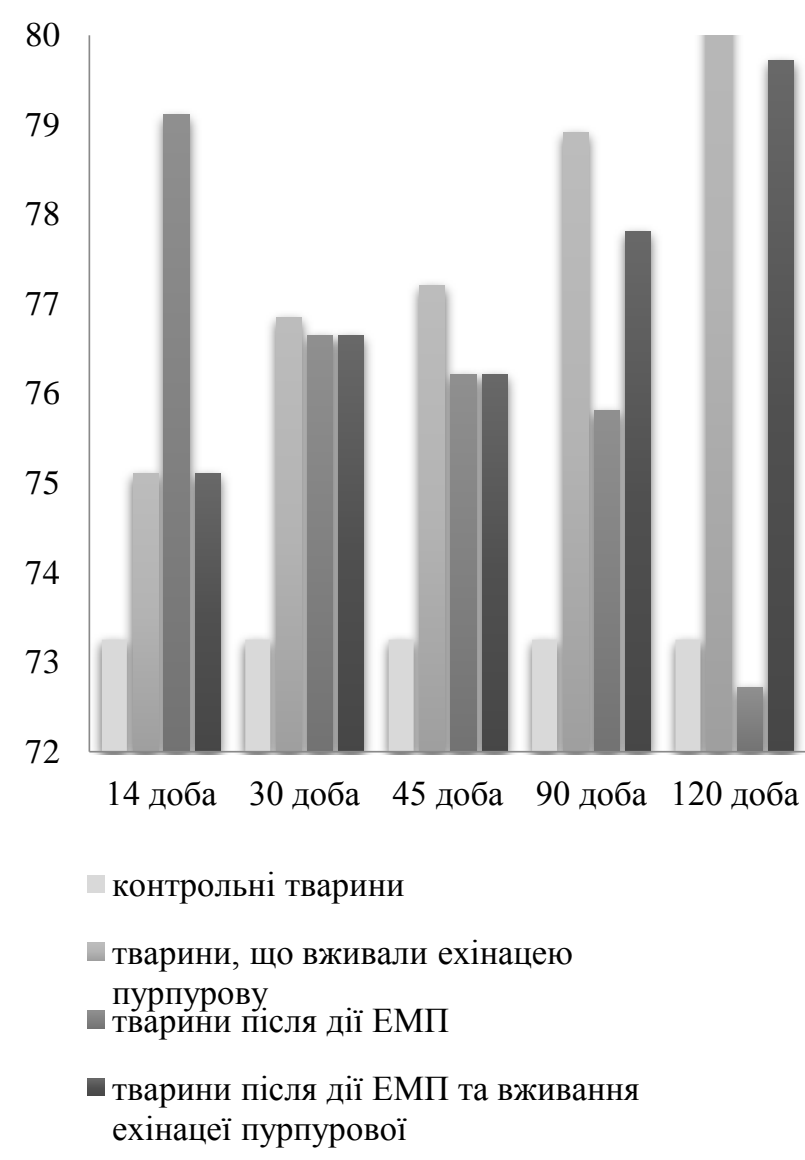

Рис. 1. Відсотковий вміст звивистих сім'яних канальців яєчок щурів після дї ЕМП, вживання ехінацеї пурпурової та поєднаної дї чинників

До 45-ї доби експерименту звивисті та прямі сім'яні канальці мали видовжену форму. Спостерігалось набухання, деформація власної оболонки канальців, десквамація сперматогенного епітелію. Епітелій характеризувався гіпохромією, вакуолізацією і лізисом цитоплазми, пікнозом i лізисом ядер. Клітини строми мали різноманітну форму, були деформованими. Лімфатичні судини охоплювали тісним кільцем кровоносні судини сім'яних канальців яєчка.

Починаючи з 45-ї доби спостереження до кінця експерименту вміст звивистих сім'яних канальців у тварин, що одержували настоянку ехінацеї пурпурової, підвищувався від 76,21士1,15\% до $79,72 \pm 2,35 \%$. Відповідно до цих показників на початку експерименту зворотньопропорційно зменшувався вміст інтерстиційної тканини в одиниці

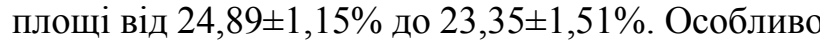
помітне зниження вмісту інтерстиційної тканини визначалося з 45-ї до 120-ї доби спостереження від 23,79 $\pm 2,05 \%$ до $20,28 \pm 1,45 \%$ (рис. 2 ).

Починаючи з 45-ї доби до 120-ї доби експерименту в морфологічній картині яєчка відбувались відновлювальні процеси, в тому числі і в структурах гематотестикулярного бар'єру. Відновлювалась пошаровість епітелію власної оболонки сім'яних канальців, менше злущених епітеліальних клітин потрапляло до просвіту канальців. Кровоносні судини розширювались в діаметрі, набували різноманітних форм. У системі гемомікроциркуляторного русла внаслідок реструктуризації ендотеліоцитів визначалось розширення просвіту судин, що зменшувало застійні явища та сприяло зменшенню тромбоутворення. Внаслідок відновлення структури судин гемомікроциркуляторного русла відбувалися зміни в звивистих сім'яних канальцях, що проявлялось у збільшенні їхнього вмісту в одиниці площі яєчка до $86,30 \pm 2,30 \%$, i, відповідно, в зменшенні вмістуінтерстиційної тканини до $13,70 \pm 0,95 \%$. Одержані показники співпадають 3 даними Грицуляка Б.В. [4] про збільшення загальної площі

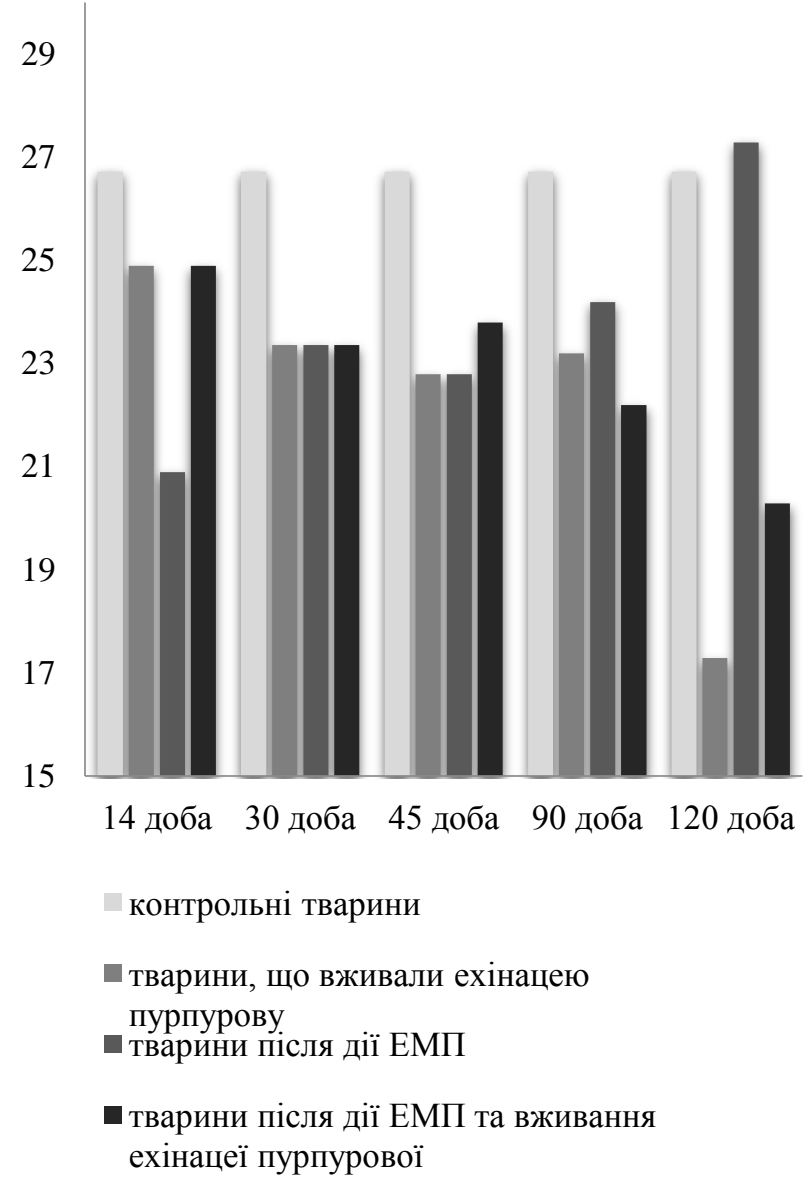

Рис. 1. Відсотковий вміст інтерстиційної тканини яєчок щурів після дї ЕМП, вживання ехінацеї пурпурової та поєднаної дї чинників 
сім'яних канальців, відновлення структур гематотестикулярного бар'єру яєчка в компенсаторнопристосувальному періоді дії пошкоджуючих факторів зовнішнього середовища, зокрема, ЕМП.

Відновлення структури власної оболонки канальців і міоїдних клітин призводили до розширення міжклітинних контактів і структурних змін клітин сперматогенного епітелію та клітин Сертоллі, внаслідок чого починалась посилена продукція анатомічно нормальних форм статевих клітин, що в свою чергу співвідноситься 3 даними Григор'єва В.В. та ін. [5] про процес активного сперматогенезу в яєчку у цей період.

Висновки. 1. Внаслідок дії електромагнітного поля високої напруги низької частоти в тканині яєчок щурів спостерігалось поступове i повільне збільшення відсоткового співвідношення сім'яних канальців і відповідно - зменшення інтерстиційної тканини. 2. У першій половині експерименту в кровопостачанні яєчок відзначалось звуження судин артеріальної ланки мікроциркуляторного русла, з середини експерименту - розширення судин венозної ланки мікроциркуляторного русла. 3. Отримані результати зумовлені позитивними властивостями настоянки ехінацеї пурпурової як імуномоделюючого препарата.

Перспективи подальших досліджень. В подальших дослідженнях доцільно визначити морфологічні зміни в яєчках щурів після впливу електромагнітного поля у віковому аспекті.

\section{Список використаної літератури}

1. Івахненко О.Л. Мужское бесплодие. Современные подходы к лечению / О.Л. Ивахненко, О.П. Стрелеч, Г.И. Кабачный // Запорожский мед. ж. - 2010. - Т. 12, № 2. - С. 65-69. 2. Юзько О.М. Статистические исследования: использование в Украине дополнительных репродуктивних технологий для лечения бесплодия / О.М. Юзько, Т.А. Юзько // Бук. мед. вісн. - 2011. - T. 15, № 3. - С. 135-137.3. Бояджян А.С. Воздействие когерентных электромагнитных волн миллиметрового диапазона на содержание различных популяций иммунных комплексов в крови / А.С. Бояджян, С.С. Акопян, Д.С. Григорян // Миллиметровые волны в биолог. и мед. - 2005. - № 2. - С. 72-76. 4. Грииуляк Б.В. Морфологія яєчка / Б.В. Грицуляк, В.Б. Грииуляк. - Ів.-Франківськ, 1998. - 133 с. 5 . Григорьев В.В. Иммунно-морфологические изменения семенников при действии сверхвысокочастотного электромагнитного поля / В.В. Григорьев, Р.П. Огурияов, Ю.Л. Зубжицкий // Арх. анатом., гистолог. и эмбриолог. - 2011. - Т. 80, Вип. 2. C. $69-75$.

\section{АНАЛИЗ РЕЗУЛЬТАТОВ МОРФОЛОГИЧЕ- СКОГО ИССЛЕДОВАНИЯ ЯИЧЕК КРЫС, ОБЛУЧЕННЫХ ЭЛЕКТРОМАГНИТНЫМ ПОЛЕМ И ПОЛУЧАВШИХ НАСТОЙКУ ЭХИНАЦЕИ ПУРПУРНОЙ}

Резюме. В данной экспериментальной работе подведены итоги морфологического исследования яичек крыс, облученных промышленным электромагнитным полем и которые потом получали 7\% спиртовую настойку эхинацеи пурпурной. Доказано, что электромагнитное поле высокого напряжения вызывает в ткани семенников морфологические нарушения базальной мембраны, сперматогенного эпителия, интерстициального пространства. Обнаруженные изменения происходили на уровне микроциркуляторного русла семенников. Употребление животными иммуномодулятора вызывает пположительные изменения в структуре яичек и тем самым способствует улучшению процесса сперматогенеза.

Ключевые слова: крыса, семенные канальцы, электромагнитное поле, эхинацея пурпурная.

\section{ANALYSIS OF THE RESULTS OF MORPHO- LOGICAL TESTICULAR EXAMINATION OF RATS EXPOSED TO ELECTROMAGNETIC FIELD AND GIVEN ECHINACEA PURPUREA TINCTURE}

Abstract. The given experimental work summarizes the morphological examination of the testicles of rats exposed to an industrial electromagnetic field and then given a 7\% Echinacea purpurea alcohol tincture. Electromagnetic field of high voltage induces morphological impairments of basal membrane, seminiferous epithelium and interstitial space in the testicular tissue. Detected changes occurred on the level of testicular microvasculature. Intake of immunomodulator by animals leads to positive alterations in testicular structure and thus promotes improvement of spermatogenesis process.

Key words: rat, seminiferous tubules, electromagnetic field, Echinacea purpurea.

Dnipropetrovsk Medical Academy (Dnipro)

Надійшла 14.04.2016 p Рецензент - проф. Хмара Т.В. (Чернівці) 